\title{
Utilization of black rice (Oryza sativa L. indica) extract in making sarabba as functional drink
}

\author{
Meta Mahendradatta ${ }^{*}$, Ulfa Mutmainnah Alri, Mariyati Bilang and Abu Bakar Tawali \\ Food Science and Technology Study Program, Department of Food Science and Technology, \\ Hasanuddin University, Indonesia
}

\begin{abstract}
Indonesian traditional drink such as Sarabba is generally consumed for its taste. However, this drink has certain functional properties which originated from its basic ingredients. To enhance its functional properties, other natural ingredients such as black rice extract can be added to the basic ingredients. Therefore, the objectives of this study were to obtain the best treatment for the use of black rice extract in producing of Sarabba and to determine the effect of drying time on proximate value, anthocyanin, and thiamine contents; and solubility level of the product. The black rice used in this study was a local type variety that contains high amount of anthocyanins, a group of flavonoids, which is beneficial to health. Black rice was mixed with water at different ratios, grinded, and filtered. The filtrate obtained was used in formulation and the drink obtained was analyzed organoleptically. The best result of sensory evaluation based on color, taste, odor and texture was found in treatment $70 \%$ rice: $30 \%$ water. The treatment with the highest organoleptic score was used in this second stage of this study which involve drying of the Sarabba drink for 1, 1.5, and 2 hours. Proximate, anthocyanin, thiamine contents and solubility of the powder were determined. The result showed that best content of water (1.67\%), carbohydrate $(0.11 \%)$ and solubility level ( 20 seconds) were obtained at two hours drying. The best content of ash (2.3\%), anthocyanin (11.83\%), thiamin $(0.056 \%)$ and fat $(0.03)$ were obtained from one hour drying. The highest protein content $(4.78 \%)$ was obtained from 1.5 hours drying treatment.
\end{abstract}

\section{Article History}

Received June 16, 2021

Accepted October 22, 2021

\author{
Keyword \\ Black rice, \\ Sarabba, \\ Anthocyanin, \\ Functional drink
}

\section{Introduction}

Indonesian people generally consume various traditional functional drinks. Sarabba is one of traditional functional drinks from South Sulawesi Province, which is widely consumed due to its health benefits. Sarabba consumed as healthy drink is traditionally made from mixture of ginger, brown sugar, and coconut milk. Ginger is the main source of bioactive compounds in Sarabba due to its high contents of gingerol and shagaol. These compounds have several health benefits such as anti-emetic (1), anti-microbial (2), antioxidant, antivirus, anti-tumor, anti-cancer (3) and immunomodulator, anti-allergic, antidiabetic $(4,5)$, anti-inflammatory (6) and other pharmacological activities. In addition, this compound is 
responsible for the spicy taste of Sarabba which makes it consumed by local people when they have influenza, fever, cough, or sore throat.

To enrich the functional properties of Sarabba, it is important to add other natural ingredients into the formulation such as black rice extract. In addition, for convenience consumption the Sarabba can be processed further into powder.

Black rice is much richer in anthocyanins, $\beta$-carotene, thiamine and tocopherol compared to other types of rice. Studies reported by several researchers indicate that black rice contains $327.6 \mathrm{mg} / 100 \mathrm{~g}$ anthocyanins (7), $804.16 \mathrm{mg} / 100 \mathrm{~g} \beta$-carotene (8), 0.46 $\mathrm{mg} / 100 \mathrm{~g}$ thiamine (9) and $12.54 \mathrm{mg} / 100 \mathrm{~g}$ tocopherol (10). However, these bioactive compounds have their own functions, such as $\beta$-carotene benefits in maintaining eye health; tocopherol maintains healthy skin, brain, eyes and fertility of reproductive organs (11); anthocyanin is a natural pigment that belongs to the flavonoid group which is responsible for the red, purple, and blue colors of food; thiamine or vitamin B1 has a function for the synthesis of pentoses which will be used as nucleic acid precursors, as a cofactor in several enzymes involved in energy metabolism, maintaining nerve function in order to function properly (12).

Based on the function compound in preventing various types of disease, black rice becomes essentials substance in producing food or drink. Furthermore, several researches have been conducted and applied to food products such as cakes, bread, pasta, noodles, and biscuit (13-16).

To the best of the author's knowledge, this is the first study to investigate the use of black rice extract in Sarabba powder formulation. The objectives of this study were to find out the best treatment for the use of black rice extract in producing Sarabba powder and the effect of drying time on proximate value, anthocyanin, and thiamine contents; and solubility level of the product.

\section{Materials and Methods}

\subsection{Preparation of black rice extract}

Black rice purchased from Enrekang Regency, South Sulawesi was cleaned from all dirt using clean water, then soaked for 45 minutes with rice to water ratio of 2:1. After that the black rice was grinded using a blender with ratio of black rice and water, 50\%:50\%; 30\%:70\%; 70\%:30\%. The suspension of black rice was then filtered to separate the solid phase from the liquid phase. The liquid phase was then used in Sarabba formulation.

\subsection{Preparation of ginger extract}

Ginger was peeled and washed from all impurities using clean water. Cleaned ginger was grated to facilitate extraction. The grated ginger was then squeezed to separate the pulp from the extract. The extract was used in Sarabba formulation.

\subsection{Preparation of coconut milk}

Coconut meat was first cleaned and grated and then water was added into the coconut with 1:2 ratio and squeezed to extract the coconut milk, which was later used in Sarabba formulation. 


\subsection{Production of Black Rice Sarabba Powder}

Brown sugar was heated in coconut milk while stirring to about $80^{\circ} \mathrm{C}$ at low heat level to avoid the breakdown of the coconut milk. After the brown sugar was completely melted, ginger extract was added while stirring and heating was continued. Black rice extract was added and stirred until the solution thicken. The thicken solution was evenly spread in thin layer on an aluminium tray then dried using oven at $100^{\circ} \mathrm{C}$ for one, one and half, and two hours.

\subsection{Sensory evaluation}

Black rice Sarabba powder was brewed with warm water in order to determine the most acceptable by the panelist. Sarabba drinks were subjected to sensory evaluation for attributes of odor, color, taste, and mouthfeel using Hedonic scoring scale with 9 scale from 1 (extraordinary dislike) to 9 (extraordinary like). The samples were tested by 25 panelists.

\subsection{Physicochemical analysis}

Black rice Sarabba powders were analyzed for their content of chemical compound namely proximate analysis (AOAC, 2005), anthocyanin (17) and thiamine content (18), and solubility level (19). Ash content was measured by weighing and furnace methods at $600^{\circ} \mathrm{C}$ for 3-5 $\mathrm{h}$ (AOAC 942.05). The protein content was measured using Kjeldahl distillation and the nitrogen value was converted to protein value using conversion factors (AOAC 960.52). Oven drying and weighing methods (AOAC 926.12) were used to measure the moisture content. Fat extraction using soxhlet distillation and chloroform as a solvent was used to measure the fat content (AOAC 948.22). The carbohydrate content was measured by difference method.

\subsection{Data Analysis}

The data of proximate analysis, anthocyanin and thiamine content were analyzed triplicate using analysis of variance using SPSS application. If a treatment has a significant effect, then Duncan's test was performed. Sensory value and solubility level were analyzed using quantitative descriptive.

\section{Results and Discussion}

\subsection{Sensory analysis}

Sensory analysis was an important test in the product development. The acceptability of a new product was always determined by the consumer of point of view. The treatment with the ratio of black rice extract and water which produces Sarabba drink was tested to the panelists for their sensory acceptability. The result was showed in Figure 1. 


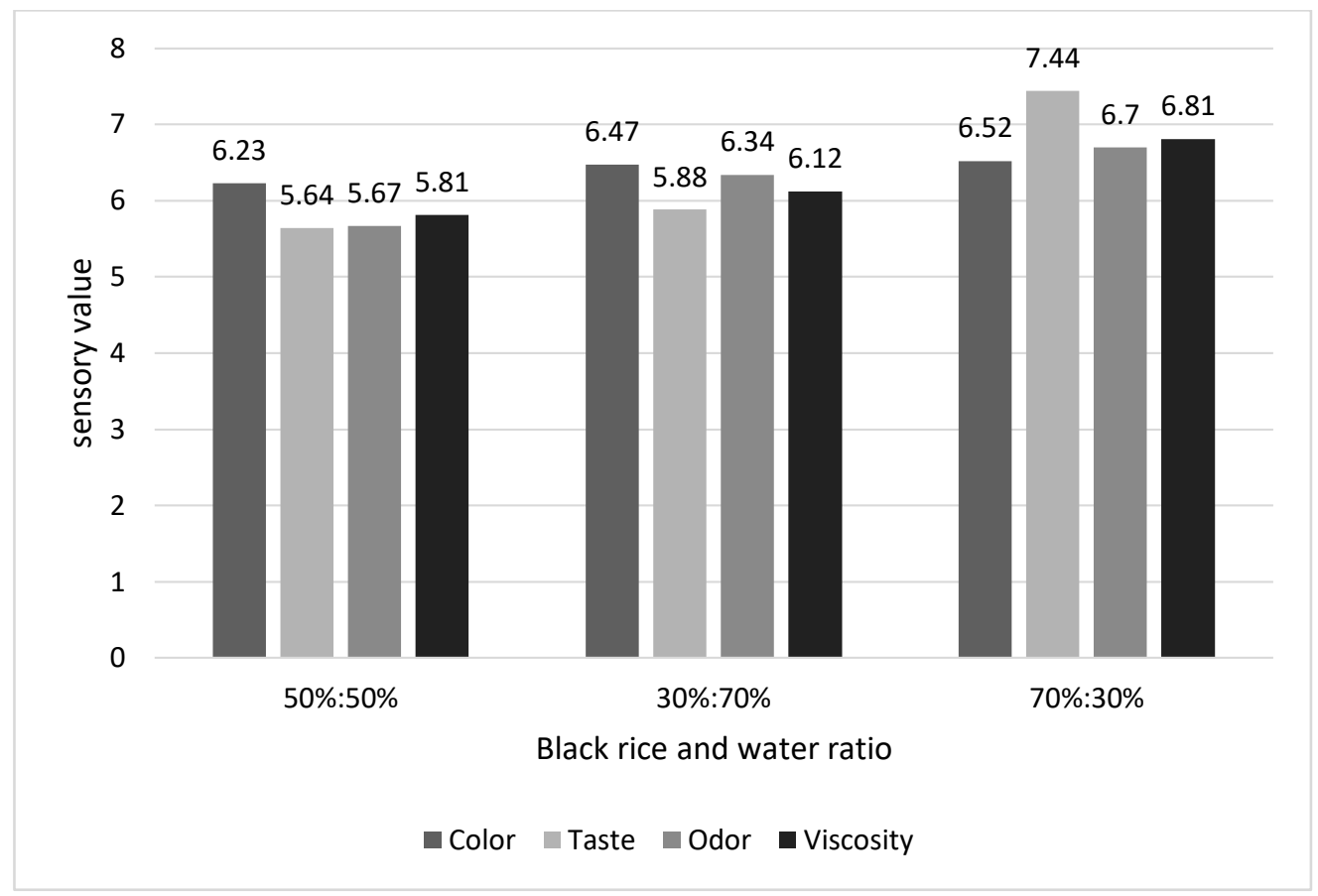

Figure 1. The effect of different ratio of black rice and water to sensory value black rice Sarabba powder.

Figure 1 showed that Sarabba drink with 70\% black rice and 30\% water was the most acceptable product. The $70 \%$ black rice and $30 \%$ water ratio resulted in dark brown color product while the color of the others was pale brown. This was caused by the highest concentration of black rice extract compared to other treatment. The increase of black rice would affect the color of Sarabba drink. In addition, the long duration of drying process resulted in Maillard reaction so that the instant Sarabba color becomes brown. This reaction caused by the reaction between reducing sugars and primary amine groups at high temperatures (20).

The odor intensity of $70 \%$ black rice and $30 \%$ water had sharp scent, but odor intensities obtained from the other ratios were lower due to the difference in the formulation of black rice extract used in each treatment. High amount of black rice extract used in the Sarabba drink would give an effect on the appearance of color, taste, odor, and mouthfeel. Besides that, the odor also comes from the nature of the material and various kinds of mixture of constituent materials such as coconut milk and ginger extract.

The higher concentration of black rice extract in $70 \%$ black rice and $30 \%$ water resulted in thicker product. The longer the drying time, the more water will be evaporated. This in turn will affect the ability of black rice Sarabba powder to absorb water when brewed and produced viscous and soft texture. This was in accordance with Rolls in 2011, who indicated that the long duration of heating process tended to cause reduction in water content (21). The sensory values of $70 \%$ black rice and $30 \%$ water ratio for viscosity, odor, taste and color were 6.81, 6.70, 7.44, 6.52, respectively. These values were higher compared to those obtained from $50 \%$ black rice and $50 \%$ water and $30 \%$ black rice and $70 \%$ water ratio (Figure 1 ). 


\section{Chemical composition and physical analysis}

The best result on sensory analysis was the $C$ treatment with ratio of $70 \%$ black rice and $30 \%$ water. Then the selected treatment was subjected to drying process and the result of proximate analysis was displayed in Table 1.

\begin{tabular}{lccc} 
Table 1. Proximate analysis of black rice Sarabba powder by different drying time. \\
\cline { 2 - 4 } Compounds & \multicolumn{3}{c}{ Drying process (hour) } \\
\cline { 2 - 4 } & $3.03 \pm 0.9504$ & $2.14 \pm 2.5773$ & $1.67 \pm 1.1547$ \\
Moisture (\%) & $4.23 \pm 0.1343$ & $4.78 \pm 0.0503$ & $3.8 \pm 0.0781$ \\
Protein (\%) & $0.03 \pm 0.0045$ & $0.06 \pm 0.0059$ & $0.172 \pm 0.0114$ \\
Fat (\%) & $2.3 \pm 0.0116$ & $2.52 \pm 0.1852$ & $2.68 \pm 0.3213$ \\
Ash (\%) & $0.37 \pm 0.4909$ & $0.09 \pm 0.0265$ & $0.76 \pm 0.0115$ \\
Carbohydrate (\%) &
\end{tabular}

The results obtained by testing the moisture content in the sample after one hour drying time was higher than 1.5 hours and 2 hours. Based on the result of the analysis of variance it showed that there was no significant effect on the moisture content of each black rice Sarabba powder so that no further tests were carried out. According to Fellow in 2000 that the higher the temperature and the longer drying time used to dry a material, the more evaporated water from the material (22), and that the longer the time and the higher the drying temperature used, the lower the water content of the material and reduce the weight of the material. Based on the results of the analysis of variance showed that there was no significant effect on ash content in each black rice Sarabba powder. The longer the drying process, the moisture content of the Sarabba product instantaneously removed the black rice juice so that the minerals left in the ingredients increased. In addition, black rice had high inorganic compounds, one of which was magnesium. The fat content in each treatment showed a significant difference $(p<0.05)$. The average fat content of black rice instant Sarabba ended to increase and it might be caused by the decrease of moisture content. This was in accordance with Yuniarti et al. that the length duration time and the high temperature used in the drying process would cause the increase of fat content and the decrease of moisture content in the material (23).

The protein content showed also a significant difference $(p<0.05)$. It might be caused of the change of protein structure after 2 hours drying time whereas during drying process for 1.5 hours it did not occur. Zhang et al. said that the protein denaturation could occur due to length time of drying process, heating, $\mathrm{pH}$ change and chemical addition (24). Based on the results of analysis of variance it showed that there was no significant effect on carbohydrate content in each treatment. According to Liu et al., carbohydrate content in black rice Sarabba powder were influenced by the proportion of moisture content, ash content, protein content and fat content (25). If the proportion is small, the levels of carbohydrates will be greater. By reducing the moisture content, food will contain compounds such as carbohydrates, proteins and minerals in higher concentrations, but vitamins and dyes generally become damaged or reduced.

Beside of proximate analysis, active compound of black rice Sarabba powder and solubility level have been also determined. The result was presented in Table 2. 


\begin{tabular}{lccc}
\hline \multirow{4}{*}{ Table 2. Proximate a nalysis of black rice Sarab ba powder by different drying time. } \\
\cline { 2 - 4 } & \multicolumn{4}{c}{ Drying process (hour) } \\
\cline { 2 - 4 } & \multicolumn{4}{c}{1.5} \\
\hline Compound & $11.83 \pm 0.1803$ & $6.99 \pm 0.8412$ & $0 \pm 0.0000$ \\
\hline Anthocyanin (mg/L) & $0.062 \pm 0.0105$ & $0.059 \pm 0.0069$ & $0.056 \pm 0.0087$ \\
Thiamine (\%) & & & \\
\hline Physical analysis & $0.14 \pm 0.0041$ & $0.19 \pm 0.0149$ & $0.25 \pm 0.02530$ \\
\hline Solubility (g/sec) &
\end{tabular}

Anthocyanin is a dye of natural substances found in food ingredients such as in aleurone of rice which gives red, purple to black color. It plays an important role in maintaining health because of its antioxidant activity as an anticancer, preventing diabetes, coronary heart disease and hypertension. Ichikawa et al. stated that anthocyanin is a compound found in brown rice, black rice and black sticky rice (26). Aleurons and endosperms produce high intensity anthocyanins so that the color of rice becomes thick red and purple to black. Based on the analysis of variance it showed that there was a significant different on the anthocyanin content in each treatment $(p<0.05)$ The anthocyanin content obtained decreased from 1 hour, 1.5 hours and 2 hours of drying time of $0 \%$ anthocyanin content. This was influenced by long drying times so that the anthocyanin content tends to decrease. Heating treatment could also cause anthocyanin equilibrium to change shape to colorless, namely carbinol and chalcone bases (27). The higher the drying temperature and the longer the drying process, the lower the anthocyanin content.

Thiamine content obtained at black rice Sarabba powder showed a significantly different $(p>0.05)$. It might influenced by long drying times. Thiamine is susceptible to damage at high heating temperatures and during prolonged drying. The higher the drying temperature and the longer the drying process, the content of thiamine will be damaged so that it decreased.

Physical analysis that has been carried out was the solubility test. Solubility is the time when all the powder dissolves completely in water. Solubility analysis was carried out to determine the speed of solubility of Sarabba powder in water when consumed. In this study solubility was calculated based on the time the beverage dissolved in seconds. The higher the solubility value obtained, the better the quality of the product produced (28). The two hour long drying process showed the fastest dissolution time compared to one hour and one and half hour drying time. This happened because of the large amount of solvent particles so that the solute became more effective by the longer drying time. It caused a lot of evaporation of moisture and the moisture content in the material is lower. So that it was easy to experience water absorption when dissolved.

\section{Conclusion}

The selected treatment based on the result of sensory evaluation on black rice Sarabba powder was the treatment with ratio of black rice and water, 70\%:30\%. Longer duration of drying process caused the decrease of moisture and protein content and also anthocyanin and thiamine content while the ash, carbohydrate, and fat content increased. The solubility of the product was better along with the duration of drying process. Based on 
the results obtained, it was recommended one hour as the suitable drying time by considering the content of active component (anthocyanin and thiamine content).

\section{Author Contributions}

Meta Mahendradatta and Ulfa Mutmainnah Alri conceived and designed the experiments; Mariati Bilang, and Abu bakar Tawali performed the experiments; Ulfa Mutmainnah Alri analyzed the data; Mariati Bilang, Abu Bakar Tawali and Ulfa Mutmainnah Alri contributed reagents/materials/analysis tools; Meta Mahendradatta and Ulfa Mutmainnah Alri wrote the paper.

\section{References}

1. Chang JS, Wang KC, Yeh CF, Shieh DE, Chiang LC. Fresh Ginger (Zingiber Officinale) Has Anti-Viral Activity Against Human Respiratory Syncytial Virus in Human Respiratory Tract Cell Lines. J Ethnopharmacol. 2013;145:146-51.

2. Semwal RB, Semwal DK, Combrinck S, Viljoen AM. Gingerols and shogaols: Important nutraceutical principles from ginger. Phytochemistry. 2015;117:554-68.

3. Behroozeh A, Tabrizi MM, Kazemi SM, Choupani E, Kabiri N, Ilbeigi D, et al. Evaluation the anti-cancer effect of pegylated nano-niosomal gingerol, on breast cancer cell lines (T47D), in-vitro. Asian Pacific J cancer Prev APJCP. 2018;19(3):645.

4. Son MJ, Miura Y, Yagasaki K. Mechanisms for antidiabetic effect of gingerol in cultured cells and obese diabetic model mice. Cytotechnology. 2015;67(4):641-52.

5. Yu L-Y, Shi W-L, Xin-Gui G. Cardio-protective role of gingerol along with prominent anti-diabetic cardiomyopathy action in a streptozotocin-induced diabetes mellitus rat model. Cell J. 2017;19(3):469.

6. Liang N, Sang Y, Liu W, Yu W, Wang X. Anti-inflammatory effects of gingerol on lipopolysaccharide-stimulated RAW 264.7 cells by inhibiting NF-kB signaling pathway. Inflammation. 2018;41(3):835-45.

7. Elvira-Torales LI, García-Alonso J, Periago-Castón MJ. Nutritional importance of carotenoids and their effect on liver health: A review. Antioxidants. 2019;8(7).

8. Apridamayanti P, Pratiwi R, Purwestri YA, Sri Tunjung WA, Rumiyati R. Anthocyanin, nutrient contents, and antioxidant activity of black rice bran of Oryza sativa L. 'Cempo Ireng' from Sleman, Yogyakarta, Indonesia. Indones J Biotechnol. 2018;22(1):49.

9. Mohammed K, Ahmary A. A simple spectrophotometric method for determination of thiamine (vitamin B1) in pharmaceuticals. Eur J Chem. 2014;5(1):81-4.

10. Kumar N, Murali RD. Black Rice: A Novel Ingredient in Food Processing. J Nutr Food Sci. 2020;10(2):771.

11. Johnson EJ. The role of carotenoids in human health. Nutr Clin Care. 2002;5(2):56-65.

12. Fattal-Valevski A. Thiamine (vitamin B1). J Evid Based Complementary Altern Med. 2011;16(1):12-20.

13. Sui $X$, Zhang $Y$, Zhou W. Bread fortified with anthocyanin-rich extract from black rice as nutraceutical sources: Its quality attributes and in vitro digestibility. Food Chem. 2016;196:910-6.

14. Kong $S$, Lee J. Antioxidants in milling fractions of black rice cultivars. Food Chem. 2010;120(1):278-81.

15. Kumar N, Murali RD. Black Rice: A Novel Ingredient in Food Processing. J Nutr Food 
Sci. 2020;10(2):771.

16. Ito VC, Lacerda LG. Black rice (Oryza sativa L.): A review of its historical aspects, chemical composition, nutritional and functional properties, and applications and processing technologies. Food Chem. 2019;301:125304.

17. Teng Z, Jiang X, He F, Bai W. Qualitative and Quantitative Methods to Evaluate Anthocyanins. eFood. 2020;1(5):339-46.

18. Al-Ahmary KM. A simple spectrophotometric method for determination of thiamine (vitamin B1) in pharmaceuticals. Eur J Chem. 2014;5(1):81-4.

19. Khami S, Khamwichit W, Suwannahong K. Synthesis of cellulose acetate nanofiber (CANF) from bacterial cellulose (BC) incubated from cannery seafood wastewater (CSW) using Acetobacter xylinum. ARPN J Eng Appl Sci. 2019;14(17):3038-45.

20. Winarno FG. Food Chemistry and Nutrition. Jakarta: Gramedia Pustaka Utama; 2004.

21. Rolls ET. Taste, olfactory and food texture reward processing in the brain and obesity. Int J Obes. 2011;35(4):550-61.

22. Fellow PJ. Food Processing Technology: Principle and Practice. New York: Ellis Horwood; 2000.

23. Yuniarti N, Syamsuwida D, Aminah A. The Influence of water content decrease on the physiological and bichemical changes of Eboni (Diospyros celebica Bakh.). J Penelit Hutan Tanam. 2008;5(3):191-8.

24. Zhang L, Zhou R, Zhang J, Zhou P. Heat-induced denaturation and bioactivity changes of whey proteins. Int Dairy J. 2021;123:105175.

25. Liu P, Li Y, Gao L, Zhou X, Ma P, Wang Q. Effect of different carbohydrates on the functional properties of black rice glutelin (BRG) modified by the maillard reaction. $J$ Cereal Sci. 2020;93:102979.

26. Ichikawa H, Ichiyanagi T, Xu B, Yoshii Y, Nakajima M, Konishi T. Antioxidant activity of anthocyanin extract from purple black rice. J Med Food. 2001;4(4):211-8.

27. Oliveira J, Azevedo J, Seco A, Mendoza J, Basílio N, de Freitas V, et al. Copigmentation of anthocyanins with copigments possessing an acid-base equilibrium in moderately acidic solutions. Dye Pigment. 2021;193:109438.

28. Kim S, Bilgili E, Davé RN. Impact of altered hydrophobicity and reduced agglomeration on dissolution of micronized poorly water-soluble drug powders after dry coating. Int J Pharm. 2021;606:120853. 